\title{
Lecture experiments in acoustics
}

\section{Professor Silvanus P. Thompson}

To cite this article: Professor Silvanus P. Thompson (1880) Lecture experiments in acoustics, Philosophical Magazine Series 5, 9:53, 75-75, DOI: 10.1080/14786448008626800

To link to this article: http://dx.doi.org/10.1080/14786448008626800

$$
\text { 册 Published online: } 28 \text { Apr } 2009 .
$$

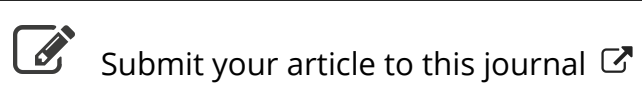

\footnotetext{
Џll Article views: 3
}

Q View related articles $\sqsubset$ 


\title{
$\left[\begin{array}{ll}75 & ]\end{array}\right.$ \\ X. Intelligence and Miscellaneous Articles. \\ LECTURE EXPERIMENTS IN ACOUSTICS. BY PROFESSOR SILVANUS P. THOMPSON*.
}

\section{Propagation of a Longitudinal Wave.}

\begin{abstract}
A PIECE of apparatus for illustrating the propagation of a longitudinal disturbance more effectively than the customary rows of suspended ivory balls, or of glass balls laid in a groove upon a table, is made by hanging to a wooden rod a row of the balls of thin caoutchouc distended with air, which are sold coloured for children's toys. There is enough tangential friction, if properly arranged, to allow of the propagation of a transversal disturbance being also shown.
\end{abstract}

\section{Demonstration of Vowel Qualities.}

The usual demonstration of the part played by the various cavities and positions of the throat and mouth in producing vowel qualities of tone is to set the air in them vibrating by resonance to the tones of appropriately chosen tuning-forks, corresponding to a harmonie series, held in front of the open mouth. The jew's harp, with its simple reed set vibrating by the finger, affords a capital adjunct to the experiments with tuning-forks. The entire set of vowel sounds, and even such simple phrases as "who are you?" (minus the consonantal sounds) may be pronounced by the jew's harp in the following manner:-The instrument is held against the slightly opened teeth in the usual manner for playing. The operator then adjusts his throat and mouth as if to pronounce the desired rowel or rowels, and, breathing softly to sustain the vibrations of the reed, strikes the turned-up end, or tongue, with his forefinger. An audience of one or two hundred people can hear the sounds without difficulty.

\section{Illustration of compounding a Rectilinear Vibraion with a Simple Translation at right angles to it.}

Let a straight piece of stout clock-spring or of flat steel "crinoline-wire" be fastened to a suitable handle, and a heavy silvered bead be attached to the other end. If this be set vibrating, the bright point produced by viewing a light by reflexion in the spherical surface of the bead appears drawn out into a line of light. If the spring be held in a horizontal plane, this line is of course vertical. Let the spring be then moved in the hand with a swift horizontal motion of translation; the line of light will then appear drawn out into a luminous sinusoidal curve.

* Communicated by the Author. 